\title{
Acute Retinal Necrosis after Herpetic Encephalitis
}

\author{
F. Kianersi A. Masjedi H. Ghanbari \\ Ophthalmology Ward, Feiz Hospital, Isfahan University of Medical Sciences, \\ Isfahan, Iran
}

\section{Key Words}

Acute retinal necrosis $\cdot$ Herpes simplex virus $\cdot$ Herpetic encephalitis

\begin{abstract}
Purpose: To report a case of unilateral acute retinal necrosis after herpetic encephalitis Case Report: A young man was referred with a chief complaint of blurred vision and pain of the left eye 1 month after herpetic encephalitis in the left frontotemporal lobe. The patient had multiple foci of retinitis in the retinal periphery associated with vitritis, blot retinal hemorrhage and retinal arteriolitis. The impression of acute retinal necrosis was confirmed by polymerase chain reaction of aqueous humor by detecting herpes simplex virus type 2; therefore, the patient received intravenous acyclovir.
\end{abstract}

Conclusion: Herpetic encephalitis may be a risk factor for acute retinal necrosis. The virus may reach the eye by the trans-axonal route. Prophylaxis with acyclovir may be necessary after herpetic encephalitis to prevent acute retinal necrosis.

\section{Introduction}

Acute retinal necrosis (ARN) is one of the clinical presentations of herpes simplex virus (HSV). This disease may present several years after a primary infection, or it may occur following systemic herpetic infection such as herpetic dermatitis. The prevalence of the disease is equal in both sexes and it occurs in the 5th-7th decade of life [1]. American Uveitis Society criteria for the diagnosis of ARN syndrome are: one or more foci of retinal necrosis with discrete borders located in the peripheral retina, rapid progression in the absence of antiviral therapy, circumferential spread, occlusive vasculopathy with arteriolar involvement, prominent vitritis, and anterior chamber inflammation. Optic neuropathy, scleritis, and pain are supportive but not required [2]. In most patients, the diagnosis is made clinically. Polymerase chain reaction (PCR) analysis of the aqueous humor can detect the cause of ARN specifically. PCR is very helpful in the detection of the varicella zoster, HSV type 1 and 2. Patients with ARN due to HSV-1 and varicella zoster virus tend to be older, whereas those with ARN due to HSV-2 tend to be younger $[3,4]$. In this article, we report one case of unilateral ARN 1 month after the herpetic encephalitis. 


\section{Case Report}

The patient is a 25 -year-old man who was admitted with a chief complaint of decreased vision and pain in left eye for the previous 4 days. The decreased vision developed gradually. The patient also complained of perception of floating objects in the visual field of the left eye. Ocular pain had no association with ocular movements. The patient had no symptoms in the right eye. The patient had no past medical history indicating an immunocompromised state; he had been admitted to the neurology ward due to herpetic encephalitis 1 month previous to the occurrence of visual symptoms. Herpetic encephalitis diagnosis was made by brain MRI (fig. 1) and PCR analysis of the cerebrospinal fluid. Brain MRI revealed left frontotemporal herpes encephalitis. The patient received intravenous acyclovir for 14 days in the neurology ward. He did not report any underlying disease or drug consumption except oral acyclovir $800 \mathrm{mg}$ every $8 \mathrm{~h}$. At physical examination, the right eye was normal. In the left eye, visual acuity was 0.1 , papillary reflex was normal and Marcus Gunn sign was negative. Red reflex was 0.4. Extraocular muscles function was normal and the eye had no deviation. The eyelid was normal. Slit lamp examination of the left eye revealed conjunctival hyperemia and ciliary injection, diffuse fine keratic precipitates in the corneal endothelium, $3+$ cellular reaction in the anterior chamber, $3+$ cellular reaction in the vitreous without snowball or snowbank opacities, or vitreous hemorrhage. In fundoscopic examination, multiple foci of retinitis and retinal necrosis were detected in the inferior, inferonasal and surpranasal peripheral retina (fig. 2) associated with arteriolar involvement (arteriolitis), blot retinal hemorrhage and optic disc hyperemia. PCR analysis of aqueous humor revealed HSV-2, so the patient was admitted with the diagnosis of ARN and received intravenous acyclovir for 10 days $(10 \mathrm{mg} / \mathrm{kg} /$ day). After $48 \mathrm{~h}$ of antiviral therapy, a systemic corticosteroid (prednisolone $1 \mathrm{mg} / \mathrm{kg} /$ day) was introduced and subsequently tapered over several weeks to treat active inflammation. The patient also received aspirin to treat an associated hypercoagulable state. With this treatment, no new lesion developed and opacity of the media decreased; so prophylactic barrier laser photocoagulation in the areas of healthy retina at the posterior borders of the necrotic lesion prevented retinal detachment. Intravitreal antiviral agents such as ganciclovir and foscarnet were not used in this patient because the disease was controlled by intravenous acyclovir. After discharge from hospital, oral acyclovir $400 \mathrm{mg}$ every $5 \mathrm{~h}$ was started. During follow-up, the inflammation decreased and the patient had no vitreous traction or retinal detachment or other eye involvement.

\section{Discussion}

In this patient, ARN occurred 1 month after herpetic encephalitis. The brain and retinal involvement were on one side; after 1 month of left frontotemporal lobe involvement of the brain, the retina was involved on the left side. Some of the studies report ARN several years after neonatal and infantile herpetic encephalitis $[5,6]$; therefore, herpetic encephalitis may be a risk factor for ARN development [7]. Other articles report that the virus accesses the retina from the brain by the trans-axonal route; consequently, this virus can cause recurrent episodes of ARN $[8,9]$. These reports may necessitate a prophylaxis with antiviral agents after herpetic encephalitis to prevent ARN. In a study by Pavésio et al. [5], the role of long-term prophylaxis with acyclovir in children who had herpetic encephalitis is an important issue. Prophylaxis could be considered after HSV encephalitis to prevent ARN or after ARN to prevent second eye involvement. Acyclovir used as prophylaxis for recurrent genital HSV infection in adults for 5 or more years has been associated with minimal toxicity and the selection of resistant strains has not been demonstrated [10], but there is little experience with the duration of prophylaxis that would have been necessary to prevent ARN in our patient. With this report we reemphasize the correlation between these two diseases. On the other hand, ARN may be an indication of possible central nervous system involvement and neuroimaging may be necessary in all cases of ARN to rule out herpetic encephalitis. 


\begin{tabular}{c|l|l|l}
$\begin{array}{c}\text { Case Reports in } \\
\text { Ophthalmology }\end{array}$ & $\begin{array}{l}\text { Case Rep Ophthalmol 2010;1:85-89 } \\
\text { DOI: 10. 1159/000321708 }\end{array}$ & Published online: & $\begin{array}{l}\text { O 2010 S. Karger AG, Basel } \\
\text { October 30, 2010 }\end{array}$ \\
$\begin{array}{l}\text { ISN 1663-2699 } \\
\text { www.karger.com/cop }\end{array}$ \\
\hline
\end{tabular}

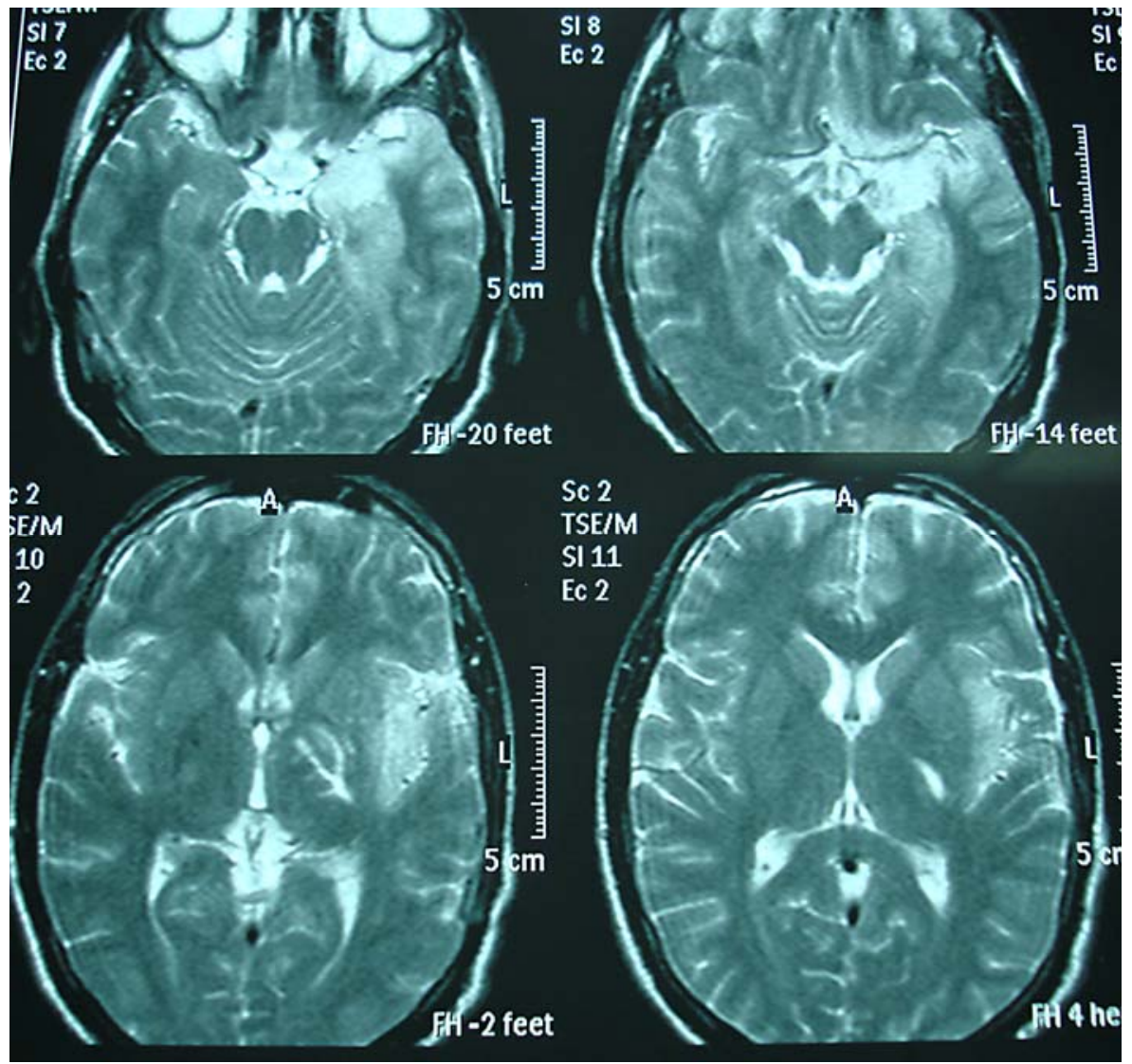

Fig. 1. Herpetic encephalitis of the left frontotemporal lobe. 


\begin{tabular}{c|l|l|l}
$\begin{array}{c}\text { Case Reports in } \\
\text { Ophthalmology }\end{array}$ & $\begin{array}{l}\text { Case Rep Ophthalmol 2010;1:85-89 } \\
\text { DOI: 10.1159/000321708 }\end{array}$ & $\begin{array}{l}\text { Published online: } \\
\text { October 30, 2010 }\end{array}$ & $\begin{array}{l}\text { O 2010 S. Karger AG, Basel } \\
\text { ISSN 1663-2699 } \\
\text { www.karger.com/cop }\end{array}$ \\
\hline
\end{tabular}
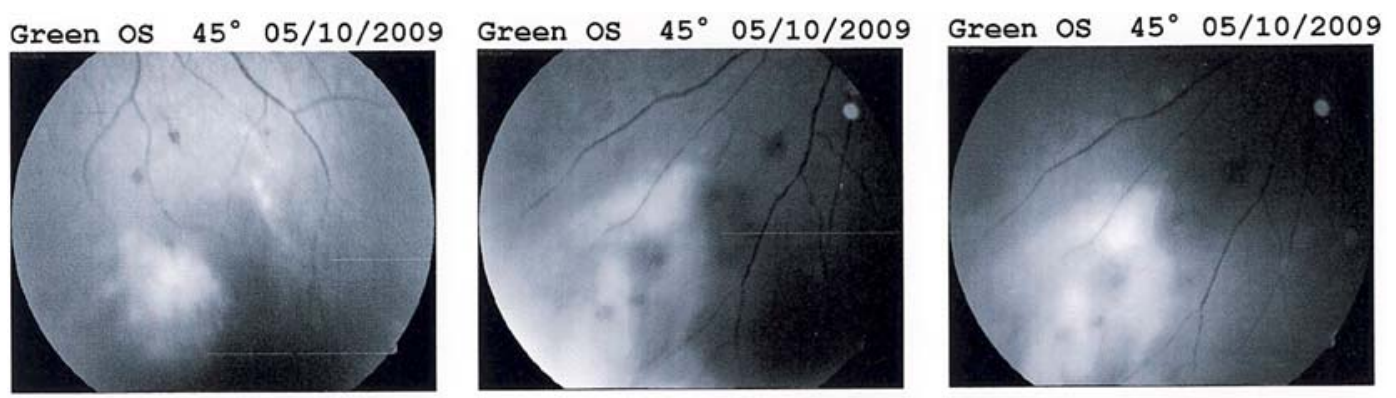

Green OS $45^{\circ} 05 / 10 / 2009$
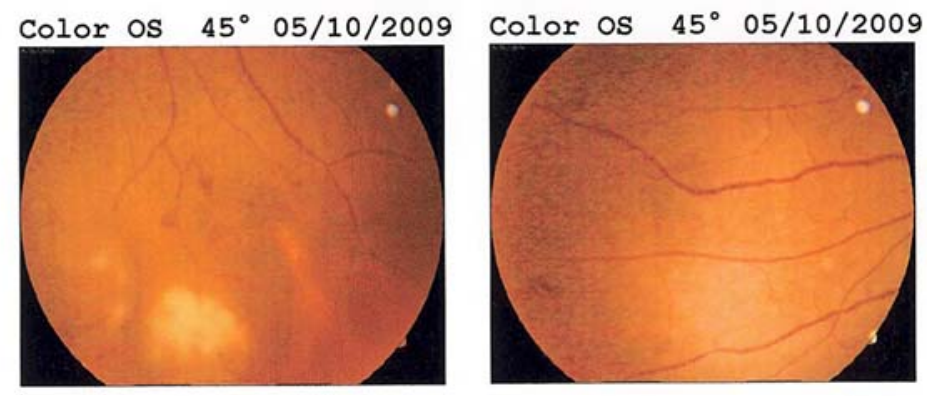

Color os $45^{\circ} 05 / 10 / 2009$

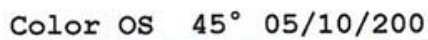

Color OS $45^{\circ}$ 05/10/2009
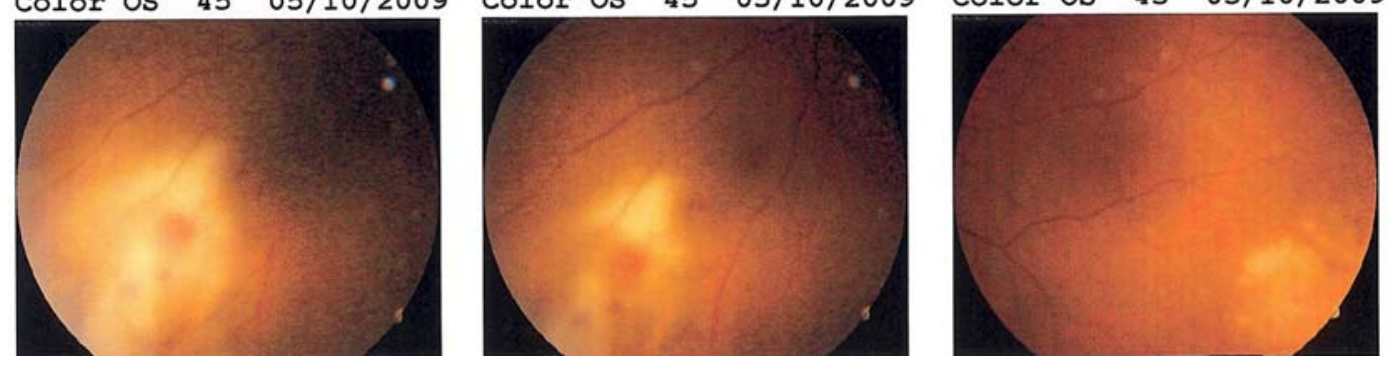

Fig. 2. Fundoscopic appearance of the left eye: retinitis, arteriolitis, and retinal hemorrhage. 


\section{References}

1 Bodaghi B, Rozenberg F, Cassoux N, Fardeau C, LeHoang P: Nonnecrotizing herpetic retinopathies masquerading as severe posterior uveitis. Ophthalmology 2003;110:1737-1743.

2 Holland GN: Standard diagnostic criteria for the acute retinal necrosis syndrome. Executive committee of the American Uveitis Society. Am J Ophthalmol 1994;117:663-667.

-3 Ganatra JB, Chandler D, Santos C, Kuppermann B, Margolis TP: Viral causes of the acute retinal necrosis syndrome. Am J Ophthalmol 2000;129:166-172.

-4 Van Gelder RN, Willig JL, Holland GN, Kaplan HJ: Herpes simplex virus type 2 as a cause of acute retinal necrosis syndrome in young patients. Ophthalmology 2001;108:869-876.

5 Pavésio CE, Conrad DK, McCluskey PJ, Mitchell SM, Towler HM, Lightman S: Delayed acute retinal necrosis after herpetic encephalitis. Br J Ophthalmol 1997;81:415-416.

-6 Thompson WS, Culbertson WW, Smiddy WE: Acute retinal necrosis caused by reactivation of herpes simplex virus type 2. Am J Ophthalmol 1994;118:205-211.

7 Vandercam T, Hintzen RQ, De Boer JH, Van der Lelij A: Herpetic encephalitis is a risk factor for acute retinal necrosis. Neurology 2008;71:1268-1274.

-8 Perry JD, Gikin CA, Miller NR, Kerr DA: Herpes simplex encephalitis and bilateral acute retinal necrosis syndrome after craniotomy. Am J Ophthalmol 1998;126:456-460.

9 Klein A, Lefebvre P: Three consecutive episodes of acute retinal necrosis due to herpes simplex-1 over twelve years following herpetic encephalitis. Ocul Immunol Inflamm 2007;15:411-413.

10 Leonard H, Goldenberg MD: Longterm suppression of recurrent genital herpes with acyclovir. Arch Dermatol 1993;129:582-587. 